\title{
Land Use Changes and Their Effects on Soil Physical and Chemical Properties in Abol woreda Gambella Regional State
}

\author{
Assistant professor Wasihun Mengiste ${ }^{1 *}$ \\ Semeneh Demise ${ }^{2}$
}

\begin{abstract}
In Abol woreda continuous cultivation, intensive grazing and investment are the major practiced in the woreda soil without out intensive care was decline in soil chemical, biological and physical properties. The current research, therefore, is intended to determine Land use Changes and consequence on Soil Physicio-Chemical Properties in Abol woreda Gambella Regional State. General visual field observation and survey were carried out and the research site was portioned in to three major land uses (cropped grazing and forest land use types). Accordingly, a total of three major land uses (cultivated grazing and forest land use types) were identified in field based on soil texture and land use systems. Finally three major land use system were identified, and from each major site, composite soil samples were taken from thirteen soil sub-samples (spots) within one depths of 0$20 \mathrm{~cm}$ using soil auger. The physico-chemical of soils was analyzed in the standardized soil laboratory procedure through the analysis of soil samples augured from three major land use systems. The results obtained from this study explore that the kebele soil did not showed the textural class difference in three land use system all showed clay loam, texture. The value of soil bulk density was increase in cropped land followed by grazing land and low in forest or reserved area land use system it ranges from $1.37,1.24$ and $1.13 \mathrm{~g} / \mathrm{cm}^{3}$ respectively. The percent of total porosity soils under the cultivated land was recorded average of 48.3 , grazing land use also $53.2 \%$ and land use forest $57.3 \%$. All of the soil chemical properties of the present research site were numerical influenced by land use system and soil textural class. For example, the highest value was recorded in basic cations $\mathrm{Ca}$ (10.02 $\mathrm{cmol} / \mathrm{kg})$, Exch-base of $\mathrm{Mg}\left(5.46 \mathrm{cmol}^{(+)} / \mathrm{kg}\right)$,Exch-base $\mathrm{K}\left(5.45 \mathrm{cmol}^{(+)} / \mathrm{kg}\right)$ and CEC $\left(28.17 \mathrm{cmol}^{(+)} / \mathrm{kg}\right) \mathrm{were}$ observed under the forestland as compared to the lowest values $(5.64,2.05 \mathrm{and} 1.97 \mathrm{cmol} / \mathrm{kg})$, respectively, in the cultivated land. The present study showed that soil fertility status decrease as land use type goes to from forest to pasture and farming lands. Hence, it is possible to infer that continuous and intensive cultivation degrade plant essential nutrients highly which urge to take action for modifying its fertility status of the agricultural soils of in the Abol district.
\end{abstract}

Keywords :-land use effect, change, physical, chemical, properties

DOI: $10.7176 / \mathrm{JRDM} / 75-01$

Publication date:May $31^{\text {st }} 2021$

\section{INTRODUCTION}

The rapid increase of world population demands more production of food, fodder, fiber and fuel required from the existing land. To achieve this issue integrated land management system being practiced in order to maintain the land from intensive cultivation and free grazing lands that are causes overgrazed and degraded in Ethiopia.

In Ethiopia, population growth and environmental factors lead to the conversion of natural forestland and grassland into cultivated farmland (Tesfahunegn, 2016) Land use changes are regarded as important components and a primary cause of global environmental changes (Turner et al., 1995; Li, 1996).

This as a result has received the major focus of global change research as its impacts on global biogeochemical cycles, climatic and hydrologic processes are profound.

These changes are driven by the interaction in space and time between biophysical and human dimensions (Turner, 1995). In most of the developing countries, its research has evolved out of efforts to identify, predict and manage ecologically damaging land use changes such as deforestation as its implications for human livelihood systems are immense.

Hence, adequate knowledge on soils of such area especially in abol woreda is mandatory in order to conserve and use the resources based on their potentials and limitations and there by maximize crop production and conserve the soils for future use. The present study involved Land use Changes and consequence on Soil chemical, physical and biological Properties at Abol area of the Gambella region. Current research topic will give good experience for the future research activities on soil related research and effects of agricultural farming on soil fertility status of the area. Therefore, this study was conducted with the general objectives of:

$>$ To determine the Land use types and their Effects on Soil Physio- Chemical Properties in Abol woreda Gambella Regional State.

Specific objective

> To investigate the effects of agricultural cultivation on selected physio-chemical properties of the soil in Abol area

$>$ To evaluate impacts of land use change on the chemical and physical properties of the soil 


\section{MATERIALSAND METHODS}

\subsection{Description of the Study Area}

The study was conducted at Abol woreda , in western Ethiopia Gambella National Regional State,. It is located at about $820 \mathrm{~km}$ western of Addis Ababa. The average altitude of the research site is about 520 meters above sea level.

Figure,1 Map of the study area

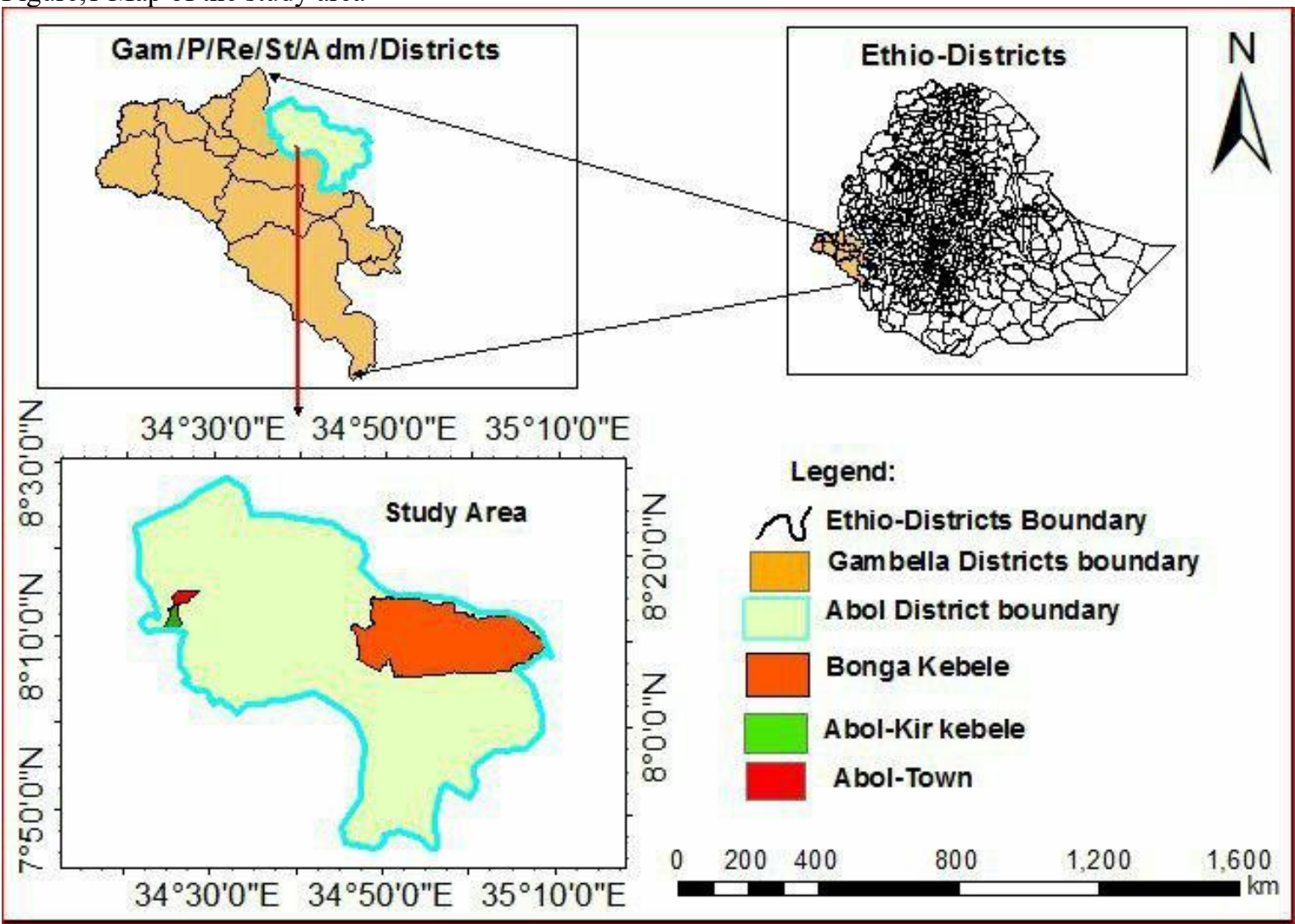

\subsubsection{Soil Sampling and Preparation}

Representative composite Soil samples were augured in the three major land uses system which is (agricultural, pasture and forest land use types). Land use system was chosen based on the current land management activities practiced in specific study area. Firstly, a general visual field observation was carried out to have a general view of the physical difference in the researched area. Based on the past land management history, the cropland selected for this study has been under cultivation for more long time whereas the adjacent grazing and forest land use types were used previously as forest and grazing use system.

From the forest lands and grazing lands, natural forest and communal grazing land were used and while from agricultural lands, cereal crop land under rain fed condition were selected. Representative soil sampling sites were chosen randomly from each land use types according to slop position. A total of three major land use type were considered and replicate four times and a total of, twelve, composite soil samples were augured from thirteen soil sub-samples within one depths of $0-20 \mathrm{~cm}$ using an auger. During soil sampling, furrow, dead plants old manures, was carefully excluded to avoid variation among the spot area. The representative composite soil samples taken from each site with four replications were air dried ground and sieved to passed through a 0.5 for total nitrogen and organic carbon and $2 \mathrm{~mm}$ sieve for the analysis of other selected soil physicochemical properties.

\subsubsection{Soil Physicochemical Analysis}

The soil samples collected from each land use system were air dried, crushed and passed through 2-mm sieve size for the determination of soil physical and chemical properties of soil except for total $\mathrm{N}$ and $\mathrm{OC}$ which were pass $0.5-\mathrm{mm}$ sieve size. Total porosity and soil bulk density were obtained from undisturbed core sampler Particle-size analysis was done using the Bouyoucos hydrometer method. Total porosity was estimated from the bulk and the particle densities as:

Total pore space $(\%)=(1-\mathrm{BD} / \mathrm{PD}) \times 100$

Where $\mathrm{Bd}=$ bulk density, and $\mathrm{Pd}=$ particle density

Laboratory analysis were carried for the chemical properties of the soil including soil $\mathrm{pH}$, total nitrogen (TN), soil organic carbon, (SOC) Available Phosphorus, Exchangeable bases (Ca, Mg, Na and K), and electrical 
conductivity (EC) on samples collected from the field. The $\mathrm{pH}$ of soil was measured potentiometrically using a $\mathrm{pH}$ meter in the suspension of 1:2.5 soils to liquid ratio of distilled water and $1 \mathrm{M} \mathrm{KCl}$ solution with combined glass electrode $\mathrm{pH}$ meter (Thomas, 1996). Organic carbon(OC) content was determined following the wet digestion method as described by Walkley and Black (1934) and percent of organic matter (OM) was calculated by multiplying $\mathrm{OC}$ by 1.724 . Total nitrogen $(\mathrm{N})$ content in the soil samples was determined titirimetrically following the Kjeldahal Procedures as described by Jackson (1958). Available P was determined by using Olsen method (Olsen et al., 1954) as outlined by Sahlemedhin and Taye (2000). The absorbance of the P extracted by Olsen method was measured using spectrophotometer after color development. Exchangeable bases $(\mathrm{Ca}, \mathrm{Mg}, \mathrm{Na}$ and K) were extracted with $1 \mathrm{~N} \mathrm{NH} 4 \mathrm{OAc}$ at $\mathrm{pH} 7$ (Van Reeuwijk, 1992). Exchangeable $\mathrm{Ca}^{2+}$ and $\mathrm{Mg}^{2+}$ were determined from the extract with EDTA; whereas $\mathrm{K}^{+}$and $\mathrm{Na}^{+}$were determined from the same extracts with flame photometer.

Extractable micronutrients $(\mathrm{Fe}, \mathrm{Mn}, \mathrm{Zn}$, and $\mathrm{Cu}$ ) were extracted with diethylene tri-aminepentaacetic acid (DTPA) and all were quantified by atomic absorption spectrophotometer at their respective wavelengths (Lindsay and Norvell, 1978).

\subsubsection{Statistical Methods}

Descriptive statistics was carried out to expose the effects and relationships between among the three land use system. Land use types were analyzed or compared with each other by considering critical values for the physico-chemical properties of Ethiopia soils.

\section{RESULT DISCUSSION AND EXPLANATION}

\subsection{Site Description of the study area}

The study was conducted at Abol district in Gambella Regional state the area is characterized by level slope and the area divided into three major land use system accordingly soil physical soil property (texture) (Table 1).Based on, the clay loam texture was dominated by level slop position $(0.5-2 \%)$ with moderately suitable soils, which occupied more than $65 \%$ of agricultural land use system were taken place in this area.

\subsection{Soil Physical Properties}

The physical properties of the study area soil showed that similarity in textural class except numerical variation among the adjacent land use systems they showed only numerical variation within land use type on the three land use type showed clay loam in texture. The highest sand fractions (37\%) was observed on the agricultural land use system whereas the highest clay percentage (38\%) was obtained in the forest land use system and the least value of clay soil textural percentage were recorded on cultivated fields which might probable due to high removal of clay by water (leaching) of clay particles down the profile in specifically agricultural fields.

Table 1.Soil Particle size distribution Abol across different land unit and land use

\begin{tabular}{|c|c|c|c|c|}
\hline Land use type & sand $\%$ & silt $\%$ & clay $\%$ & textural class \\
\hline \multicolumn{5}{|c|}{ Soil texture } \\
\hline Forest land & 27 & 35 & 38 & $\mathrm{CL}$ \\
\hline Grazing land & 34 & 37 & 29 & CL \\
\hline Cultivated land & 37 & 36 & 27 & CL \\
\hline
\end{tabular}

$\mathrm{FL}=$ forest land $\mathrm{GL}=$ grazing land $\mathrm{CL}=$ cultivated land, $\mathrm{Cl}=$ clay loam

The texture of the soil determined in the field (feel method) was similar in most cases to the determinations carried out in the laboratory (Table 1). The textural class of the all land use system were obtained similar which is Clay loam, This result explore that the different land use types did not have effect on the soil texture of the study area, since texture is an permanent and intrinsic soil property that not influenced in short period of time with management practice.

Despite the fact that texture is permanent soil property, human management practices cannot alter to changes in particle size (Table 1).

Low clay and silt; and higher sand content in the soil of agricultural lands and grasslands are attributed to the selective removal of clay particles by processes of erosion, leaving behind the sand fraction in situ.

The cultivated land and grasslands (overgrazed) are more vulnerable to erosion as they have little or no protective vegetation cover. Thus, when erosion occurs, the finer and lighter materials are selectively removed.

The absence of protective vegetation covers in the surface soil of cultivated land and grasslands soil leads to directly contributes to the removal of soil finer particles size as it reduces the organic matter that flocculate soil aggregates and increase soil loss in erosion (Abbasi et al., 2007).

\subsection{Soil bulk density and total porosity}

In general, the bulk densities of soils were low in all research sites the soils belong to fine textured soils known to have lower bulk densities (Table 2). Soils tend to be organized in porous grains or granules, especially if 
adequate organic matter content is present (Brady, 1990) which is the case. In line with this Larson et, al. (1980) also reported a bulk density rise from 0.95 in plow layer to $1.00 \mathrm{~g} / \mathrm{cm}$ in lower subsoil's from Oxisols clays in Brazil. It was lowest in soils under forest land and surface soils while highest in cultivated lands use types.

Table 2.soil Bulk density and porosity as influenced by different land use type

\begin{tabular}{lcc}
\hline Land use type & $\mathrm{BD}\left(\mathrm{g} / \mathrm{cm}^{3}\right)$ & $\mathrm{TP} \%$ \\
\hline Forest land & 1.13 & 57.3 \\
Grazing land & 1.24 & 53.2 \\
Cultivated land & 1.37 & 48.3
\end{tabular}

$\mathrm{BD}=$ bulk density, $\mathrm{TP}=$ total porosity $\mathrm{GL}=$ grazing land $\mathrm{CL}=$ cultivated land $\mathrm{FL}=$ forest land

The present study observed variation in bulk density value lowest in forest land $\left(1.13 \mathrm{~g} / \mathrm{cm}^{3}\right)$ flowed by grazing land $\left(1.24 \mathrm{~g} / \mathrm{cm}^{3}\right)$ and highest in cultivated land $\left(1.37 \mathrm{~g} / \mathrm{cm}^{3}\right)$ (Table 2).this might be due to the effects of high animal trampling by grazing animals in grazing and cultivated lands and high OM content in forest land.

The other reason that can explain the change in bulk density is attached to the intense tillage practices. Cultural tillage practices could also temporarily loosen the tilled soil layer, in the long term it increases soil bulk density due to compaction. Absence of soil surface cover soil were expose to direct impact of rain drops under fields with long period of continuous cultivation might have also contributed to the increment of bulk density as raindrop impacts cause soil compaction through disintegration of the soil structure. This creates unfavorable plant growth environment through limiting root growth and air circulation which in turn has implications for agricultural productivity.

As total porosity values were derived from manipulating values of bulk and particle densities, this characteristic showed almost similar pattern of differences as that of the bulk density values. Total porosity of the study area soils registered between 48.3- 57.30\% (Table 2). The lowest (48.3\%) and highest (57.30\%) total porosity were observed in the forest and cultivated land use type, respectively. According to London (1991), sands with a total pore space of less than $40 \%$ are liable to restrict root growth due to excessive strength whilst in clay soils, limiting total porosities are higher and less than $50 \%$ can be taken as corresponding value. Hence, the value of total porosity lies almost in the usual range (30\% and 70\%). The results obtained from the current study area are in agreement with the findings reported by other researchers (Singh et al., 1995; Maddonni et al., 1999).

\subsection{Responses of Soil Chemical Properties to Land Use Changes \\ 3.4.1. Soil $\mathrm{pH}$ and electrical conductivity}

In all of the land use system described, soil $\mathrm{pH}$ values measured in a suspension of 1:2.5 soil to water ratio (pH in $\mathrm{H}_{2} \mathrm{O}$ ) were greater than the $\mathrm{pH}$ values measured in the same ratio of soil to $\mathrm{KCl}$ solution ( $\mathrm{pH}$ in $\mathrm{KCl}$ ). Land use systems changes from pasture land use system to crop land use system showed that in relatively slightly decline of soil $\mathrm{pH}$ of the current research area. For example, the highest value (8.56) and the lowest value (7.64) soil $\mathrm{pH}$ were obtained under the forest land use system and cultivated lands, respectively (Table, 3 ).

The least value obtained from soil $\mathrm{pH}$ under the agricultural land use type system might be due to low exchangeable bases and absence of application house refuse in the farm land and crop mining.

The highest values of soil $\mathrm{pH}$ under natural forest and grazing land use system probable due to higher values this may be due to better content of exchangeable bases and low low human disturbance in the specific area. This is evident from the positively relation between soil $\mathrm{pH}$ and the exchangeable bases in both land use system. Generally the effect of land use system was showed slightly variations in soil $\mathrm{pH}$ in the study area. Considering the soil $\mathrm{pH}\left(\mathrm{H}_{2} \mathrm{O}\right)$, the soils in the present study area forest land rated as strongly alkaline and grazing and cultivated land use rated as moderately alkaline, (Table 3) according to classification set by Tekalign (1991).

Soil EC of the research site again exhibited the same trend with $\mathrm{pH}$. It was showed small variation among land use. The lowest figures in electrical conductivity were agricultural land use system and followed by pasture land and higher value obtained in forest in land use types.

The lowest value of EC was registered under agricultural fields and can be related to the loss of $\mathrm{Ca}$ and $\mathrm{Mg}$ by crop mining and containing soluble salts after deforestation and cultivation. In addition the decline in electrical conductivity in agricultural fields is the implication of decreasing basic cations which forms the soluble salt that ultimately enhances electrical conductivity.

\subsubsection{Organic matter}

The amount of soil organic matter (OM) was relatively higher in the forest land use followed by grazing land use and lowest in cultivated land use. Considering the forest soils, the highest (5.32\%) OM content was measured and $(4.27 \%)$ and lowest $(2.56 \%)$.

Most cultivated soils of Ethiopia are poor in organic matter contents due to low amount of organic materials applied to the soil and complete removal of the biomass from the field (Yihenew, 2002), and due to severe deforestation, steep relief condition, intensive cultivation and excessive erosion hazards (Eylachew, 1999).

Organic matter content was registered higher value on the natural forest land use system and medium under 
pasture land use types which might be due to the contribution of vegetation cover and less disturbance by anthropogenic and animal. Tate (1987) also reported similar findings that agricultural management of crooped land soil induces a drastic change in the equilibrium of soil OM attained under undisturbed conditions, and thereby affects its quantity and quality especially in the near surface soil.

Table 3. The three land use system influenced by some chemical properties of soil

LU type $\mathrm{pH}\left(\mathrm{H}_{2} \mathrm{O}\right) \quad \mathrm{pH}(\mathrm{KCl}) \quad \mathrm{ECe}\left(\mathrm{dS} \mathrm{m} \mathrm{m}^{-1}\right) \mathrm{OM}(\%) \mathrm{C}: \mathrm{N}$ ratio Total $\left.\mathrm{N} \%\right) \mathrm{Av} \mathrm{P}(\mathrm{mg} \mathrm{kg}-1)$

\begin{tabular}{llllllll}
\hline FL & 8.567 .42 & 0.43 & 5.32 & 10 & 0.46 & 30 & \\
GL & 7.94 & 6.87 & 0.34 & 4.27 & 11 & 0.28 & 23 \\
CL & 7.64 & 6.66 & 0.25 & 2.56 & 11 & 0.22 & 21 \\
\hline
\end{tabular}

$\mathrm{FL}=$ forest land $\mathrm{GL}=$ grazing land $\mathrm{CL}=$ cultivated land $\mathrm{EC}=$ Electrical conductivity $\mathrm{OM}=$ organic matter $\mathrm{C}: \mathrm{N}=$ carbon to nitrogen ration $\mathrm{TN}=$ Total Nitrogen $\mathrm{Av} \mathrm{P}=$ available phosphorus

\subsubsection{Total nitrogen}

The nitrogen content of the study area soil showed that numerical decline among the major land use system with similar arrangement of SOM (Table 3). In addition, the findings showed that the soil in the forest, pasture and agricultural land use system, had $0.46 \%, 0.28 \%$ and $0.22 \%$ of total nitrogen $(\mathrm{N})$ content of respectively. Generally total nitrogen content on agricultural field depleted by $52 \%$ as compared to forest land and $21.24 \%$ from adjacent grazing land use system.

Relatively better vegetation cover in grazing and forest land resulted higher OM content which might contribute to have higher total nitrogen content in the respective land use system. This findings supported by many authors (Jaiyeoba, 2003; Heluf and Wakene (2006); Abbasi et al., 2007).

\subsubsection{Available phosphorus}

The available $\mathrm{P}$ content in current study area had registered higher value in all land use types forest soil registered $30 \mathrm{mg} / \mathrm{kg}$ followed by grazing land $23 \mathrm{mg} / \mathrm{kg}$ and lowest value under cultivated land use system 21 $\mathrm{mg} / \mathrm{kg}$ (Table 3).

This finding showed that available P content of soils numerical change when we go from forest to cultivated land use system.

Available $\mathrm{P}$ content of the agricultural field showed decreased by $30 \%$ from forest and $8.69 \%$ from grazing land use system this variation or decline could be due to crop mining and crop residue removal from the field for many reasons.

The highest value of available phosphorus in the protected forest soil could be arise due to high content of soil organic matter resulting in the release of organic phosphorus. Probably for this reason, available P is highly associated with SOM content.

Based on the rating set by Carrowet al. (2004), P-Olsen between 12 to $18 \mathrm{mg} \mathrm{kg}^{-1}$ is categorized as sufficient range in all land use. This finding is in line with (Hartz, 2007). It was suggested that soil P is more dominant in warm climate than in cool climate. Therefore, phosphorus content in the current research site could be due to hot climatic condition in the study area might have been favored of the study area along with the convenient $\mathrm{pH}$ range. This result is in line with the research results reported by two authors (Yacob, 2012; Teshome, 2013) that available $P$ content of soils in the Gambella region had high range.

\subsubsection{Exchangeable bases}

The average soil exchangeable calcium of the current study area of Abol districts are 10.02 and $5.46 \mathrm{cmol}(+) / \mathrm{kg}$ (Table 5) in the forest land use respectively and 7.07, 2.96 $\mathrm{cmol}(+) / \mathrm{kg}$ whereas cultivated land use registered lowest contents compared to adjacent land use types which is $5.64,2.05 \mathrm{cmol}(+) / \mathrm{kg}$ calcium and magnesium respectively.. According to (FAO, 2006a) exchangeable calcium and magnesium is falls or rated as high rate value.

Exchangeable bases showed the highest concentration of bases registered in the forest and grazing land use system this value highest could be probably due to the contribution of addition of more farmyard manure (FYM) and the presence of high organic matter content (Appendix 2). This finding consistent with this finding, reported by many researchers that exchangeable bases were highly influenced by soil organic matter content, soil texture and management practice (Taye et, al., 2003; Heluf and Wakene, 2006).

The minimum value of exchangeable base was registered under agricultural land use system and higher at adjacent forest land use system this might be the result of mismanagement of land might have less organic matter content and less exchangeable bases due to complete removal of crop biomass from agricultural reported by Singh et al. (1995) and He et al. (1999). This finding is consistent with the findings of (Taye et. al., 2003; Heluf and Wakene, 2006). Exchangeable bases were highly influenced by OM content of the soil maintained due to virgin land management or added to the soil of cultivated land. 
Table 4. Exchangeable bases on soil under three land use types

\begin{tabular}{lrrrrr}
\hline LU type & \multicolumn{5}{c}{ Exchangeable cations_(cmol $(+) / \mathrm{kg})$} \\
\hline & $\mathrm{Ca}$ & $\mathrm{Mg}$ & $\mathrm{K}$ & $\mathrm{Na}$ & $\mathrm{TEB}$ \\
& & & & & \\
\hline FL & 10.02 & 5.46 & 3.45 & 2.02 & 17.34 \\
$\mathrm{GL}$ & 7.07 & 2.96 & 2.58 & 1.96 & 13.22 \\
$\mathrm{CL}$ & 5.64 & 2.05 & 1.97 & 1.07 & 9.87 \\
\hline
\end{tabular}

$\mathrm{TEB}=$ total exchangeable base, $\mathrm{GL}=$ grazing land, $\mathrm{FL}=$ forest land and $\mathrm{CL}=$ cultivated land,

Based on the ratings set by FAO (2006), calcium $(\mathrm{Ca})$ and magnesium $(\mathrm{Mg})$ of exchangeable bases contents under forest land use system was categorized as high rate level and ( $\mathrm{K}$ and $\mathrm{Na}$ ) were rated as very high in forest land use system whereas grazing land use type falls under medium condition in the exchangeable bases (Ca and $\mathrm{Mg}$,) and high rete value for $(\mathrm{K}$ and $\mathrm{Na}$ ) and agricultural land use types was rated as medium for all exchangeable base.

Generally exchangeable bases were slightly influenced by land use type (Table 5). Considering the land use system lower exchangeable bases were registered under forest land and lower in the agricultural fields this indicates that frequent farming and mismanagement grazing contribute to crop mining and animal grazed deplete exchangeable base in the study area.

The Cation exchange capacity of the current research site was influenced by land use types and soil texture. The highest value was registered $\left(51.08 \mathrm{Cmol} / \mathrm{kg}^{-1}\right.$ soil) under forest land use type's soil while the lowest $\left(46.74 \mathrm{Cmol} / \mathrm{kg}^{-1}\right)$ was obtained under agricultural land use types (Table 5).

The soil Cation exchange capacity values in the agricultural land use showed decline trend mainly due to the reduction in organic matter contents compared to adjacent land use system.

\subsubsection{Present base saturation and cation exchange capacity}

Table 5. Percent base saturation and Cation exchange capacity and of the soils under the three land use types

\begin{tabular}{lcll}
\hline LU type & CEC $\left(\mathrm{cmol}_{\mathrm{c}} \mathrm{kg}^{-1}\right)$ & PBS $(\%)$ & ESP $(\%)$ \\
\cline { 2 - 4 } FL & 51.08 & 33.94 & 3.95 \\
GL & 48.12 & 27.47 & 4.07 \\
CL & 46.74 & 21.11 & 2.28 \\
\hline
\end{tabular}

$\mathrm{GL}=$ Grazing land $\mathrm{CL}=$ Cultivated land $\mathrm{FL}=$ Forest land $\mathrm{PBS}=$ Percent base saturation

$\mathrm{CEC}=$ Cation exchange capacity

Basically, Cation exchange capacity is the capacity of the soil to hold and exchange cations. It provides a buffering effect to changes in $\mathrm{pH}$, available nutrients, calcium levels and soil structural changes. Organic matter particularly plays important role in exchange process because it provides more negatively charged surfaces than clay particles do. On the contrary percent base saturation was influenced by land use types.

The exchangeable bases of the soil that affect extent of bases also affect PBS (Table 5). It has declined from 33.94 in the forest soils to 21.11 and 27.47 in cropped and grazing soils respectively. It may not be surprising to note that deforestation and conversion to agricultural land use result in numerical changes in percent base saturation. This is usual as far as there exists loss of exchangeable bases and since percent base saturation by itself is a straight function of exchangeable bases.

Therefore, the reduction in PBS values from 33.94 in forest soil to 21.11 in agricultural soil also can be attributed to the observed general reduction of bases with increasing depletion of organic matter content.

\subsubsection{Available micronutrients}

In terms of soil chemical fertility, one cannot talk about the complete fertility of soils in the absence of micronutrients. Though they are required in equally important, they are as essential as the macronutrients. Therefore, their adequate presence and availability like their counterpart primary nutrients in the soil is highly necessary for the productivity of soils. Unfortunately, there is no enough information on micronutrients of Ethiopian soils in general and particularly in the current study site.

Highest numerical variation were registered on micronutrients of $\mathrm{Zn}, \mathrm{Cu}, \mathrm{Fe}$ and $\mathrm{Mn}$ on the three land use system where the highest value registered $\left(17.05,14.52\right.$ and $\left.10.22 \mathrm{mg} \mathrm{kg}^{-1}\right)$ under the forest, grazing and cropped land use system respectively for extractable iron, 15, 12.3 and 10.8, 2.84, 1.44, 1.22 and 3.53, 2.23 and 2.16 for $(\mathrm{Mn}, \mathrm{Zn}$, and $\mathrm{Cu})$ in the three land use types 
Table 6. Extractable micronutrient of the soils in two land use types Land unit extractable micronutrient $\left(\mathrm{mg} \mathrm{kg}^{-1}\right)$

\begin{tabular}{lcccc}
\hline Land use types & Fe & Mn & Zn & $\mathrm{Cu}$ \\
\hline Forest land & 17.05 & 15 & 2.84 & 3.53 \\
Grazing land & 14.52 & 12.3 & 1.44 & 2.23 \\
Cultivated land & 10.22 & 10.8 & 1.22 & 2.16 \\
\hline
\end{tabular}

The high variability of micronutrients among land use types could be probable due to differences cultural soil management practices in the area, land use, OM application Fisseha (1996) reported similar phenomena as a result of exploring micronutrient status of three Ethiopian Vertisols landscapes. Heluf and Wakene (2006) also reported that micronutrients were highly influenced by different land use systems and significant variation was observed among the different land use systems.

\section{CONCLUSIONS}

Sustainable agriculture system requires high investment effort in order to sustain the soil resource wisely because soil is a non-renewable and it is highly important precious resource, determining the agricultural potential of a given area. Hence, study and understanding of soil physical, chemical and biological properties and behavior is crucial for the development of soil management plan for efficient utilization of land resource.

Findings on this research suggest that most of soil chemical properties showed slightly reduced in cropped land use types as compared to adjacent forest land use types due to crop mining and intensive grazing without management. The textural class of the study area soils of all land use systems did not showed textural difference among land use types all showed similarity which is clay loam all the three land use system this indicating the similarity in parent material from which the soil is formed moreover soil texture is an inherent soil property that cannot be influenced in short period of time.

The results of this study are evidences of significant changes in the quality attributes of the soils in the study area following the removal or destruction of vegetative cover and frequent tillage that lead to soil erosion and thereby declining soil fertility.

\section{RECOMMENDATION}

The information obtained from this study will help in developing sustainable and ecologically sound soil conservation or management strategies in Abol area. Moreover, different governmental and non-governmental organizations, people living in the area and others stake holders who intend to invest on land should collaborate each other to maintain and conserve this precious to benefit the current and future generation without depleted.

\section{REFERENCE}

Anon. 1993. Soil Chemical Analysis. Part I, Vol. 1. Improvement of soil services for Agricultural development (Eth./87/010). Ministry of Natural Resources Development and Environmental Protection. UNDP, FAO, Addis Ababa, Ethiopia.

Brady, N.C., 1990. The nature and properties of soils. $9^{\text {th }}$ edition. MacMillan Publishing

Co. Inc. New York. 750p.

Brady, N.C. and R.R. Weil, 2002.The nature and properties of soils, 13th Ed. Prentice- Hall Inc., New Jersey, USA.960p. Hillel, D., 1980.Fundamentals of soil physics.Harcourt Brace Jovanivich Publisher, Academic Press, Inc. San Diego. 413p.

Carrow, R.N., Stowell, L., Gelernter, W., Davis, S., Dunca, R.R. and Skorulski, J. 2004. Clarifying Soil Testing: III. SLAN (Sufficiency Level of Available Nutrients) sufficiency ranges and recommendations.

EylachewZewdie, 1999. Selected physical, chemical and mineralogical characteristics ofmajor soils occurring in Chercher highlands, eastern Ethiopia.Ethiopian Journal of NaturalResource. 1(2): 173-185.

FAO (Food and Agriculture Organization). 2006a. Plant nutrition for food security: A guide for integrated nutrient management. FAO, Fertilizer and Plant Nutrition Bulletin 16. FAO, Rome

Foth, H.D. and B.G. Ellis., 1997.Soil fertility, 2nd Ed. Lewis CRC Press LLC., USA. 290p

Fisseha Itanna.1996. Micronutrient status of three Ethiopian vertisol landscapes at different agroecological zones. In: Teshome Yizengaw, Eyasu Mekonnen,and Mintesinot Behailu (eds.). 1996. Soils Information and Database: The Basis for Improved Agricultural Productivity and Sustainable Land Resource Management. Proceedings of the third conference of Ethiopian Society of Soil Science (ESSS), February 28-29, 1996, Addis Ababa, Ethiopia. 194p.

Genxu, W., M. Haiyan, Q. Ju and C. Juan, 2004. Impact of land use changes on soil carbon, nitrogen and phosphorus and water pollution in an arid region of northwest China. Soil Use and Management 20: 32-39.

He, Z.L., A.K. Alva, D.V. Calvert, Y.C. Li and D.J. Banks, 1999. Effects of nitrogen

fertilization of grapefruit trees on soil acidification and nutrient availability in Riviera fine sand. Plant and Soil. 
206: 11-19

Hartz, T.K. 2007. Soil Testing for Nutrient Availability. Procedures and Interpretation for California Vegetable Crop Production. University of California.

Heluf Gebrekidan and Wakene Negasa. 2006. Impact of land use and management practices on chemical properties of some soils of Bako area, Wetern Ethiopia. Ethiopian Journal of Natural Resources. 8 (2): $177-$ 197.

Jaiyeoba, I.A., 2003. Changes in soil properties due to continuous cultivation in Nigerian semiarid Savannah. Soil Tillage and Research 70: 91-98.

Jackson, M. L. 1973. Soil Chemical Analysis. New Delhi: Prentice Hall of Indian Pvt. Ltd. P 498.

Lindsay, W.L. and Norvell, W.A. 1978. Development of a DTPA soil test for zinc, iron, manganese and copper. Soil Sci. Soc. Am. J 42: 421-428

Landon, J.R. (ed.). 1991. Booker Tropical Soil Manual: a handbook for soil survey and agricultural land evaluation in the tropics and subtropics. John Wiley \& Sons Inc., New York.

MesfinAbebe. 1998. Nature and Management of Ethiopian Soils. Alemaya University ofAgriculture.

Olsen, S.R., Cole, C.V., Watanabe, F.S. and Dean, L.A. 1954. Estimation of available phosphorus in soil by extraction with sodium bicarbonate.USDA circular 939.1-19p.

Sahlemedhin Sertsu and Taye Bekele. 2000. Procedures for Soil and Plant Analysis. National Soil Research center, Ethiopian Agricultural Research organization.

Singh, C.J., K.M. Goh, W.J. Bond and J.R. Freney, 1995. Effects of organic and inorganic calcium compounds on soil solution $\mathrm{pH}$ and Al concentration. European J. Soil Sci. 46: 5363.

Solomon, D., J. Lehmann, M. Tekalign, F. Fritzsche and W. Zech, 2002. Phosphorus forms and dynamics as influenced by land use changes in the sub-humid Ethiopian highlands. Geoderma 105: 21-48.

Tate, R.L. 1987. Soil Organic Matter: Biological and Ecological effects. John Wiley, New York

Taye Kufa, Mesfin Abebe, and Paulos Dubale. 2003. Contribution of organic amendment to physico-chemical conditions of coffee nursery media. In: Tilahun Amede and Eylachew Zewdie (eds.). 2003. Challenges of land Degradation to Agriculture in Ethiopia. $5^{\text {th }}$ Ed. Prentice-Hall of India, New Delhi. 684p.

Tekalign Mamo and I. Haque, 1991. Phosphorus of some Ethiopian soils. 111. Evaluation of some soil test methods for available phosphorus. Tropial Agriculture. 68(1): 556.

Teshome Yitbarek, 2013 Soil Survey, Impacts Of Land Use on Selected Soil Properties and Land Suitability Evaluation in Abobo Area, Gambella Regional State of Ethiopia. Phd Dissertation, Haramaya University.

Tesfahunegn, G. B. (2016). Soil quality indicators response to land use and soil management systems in Northern Ethiopia's catchment, Land Degrad. Dev.,27: 438-448, doi:10.1002/ldr.2245,

Thomas, G.W., 1990. Exchangeable cations. In: Methods of soil analysis, Part 2. (eds.) L. Page, R. Miller and R. Keeney. pp. 159-166. American Society of Agronomy, Madison,WI.

Turner, B.L, D. Skole and S. Sanderson, 1995. Land-use and land-cover change: Science/Research plan. IGBP Report 35 / HDP Report 7. IGBP Press Stockholm and Geneva. 165p

Yacob Alemayehu, 2012. Characterization and classification of soils at Abobo agricultural research site, Gambella Region, southwest Ethiopia. M.Sc. Thesis Submitted to School of Graduate Studies, Hawassa University, Ethiopia.

YeshiBer Consultant. 2003. Gambella Peoples Regional State land use/land allotment study.Amended draft final report. Addis Ababa. Ethiopia.

YihenewGebreselassie, 2002. Selected chemical and physical characteristics of soils AdetResearch Center and its Testing Sites in North-Western Ethiopia.Ethiopian Journal ofNatural Resources. 4(2): 199-215.

Woldeamlak Bewket and L. Stroosnijder, 2003. Effects of agro-ecological land use succession on soil properties in the Chemoga watershed, Blue Nile basin, Ethiopia. Geoderma 111: 85-98. 